All rights reserved. No part of this publication may be reproduced or transmitted in any way or by any means, except for brief quotations in reviews and criticism, without prior permission of the Copyright Holder.

\title{
Danksagung - Acknowledgements
}

Für ihre freundliche Unterstützung und Hilfeleistung sei folgenden Personen herzlichst gedankt: Frau Gertrude Vogel (Pulkau), Herrn Helmut Peschina (Wien), Dr. Norbert Griesmayer (Wien), Dr. Elisabeth Lebensaft (Österreichisches biographisches Lexikon, Wien).

Für finanzielle Unterstützung danken wir der Österreichischen Gesellschaft für Literatur (Frau Marianne Gruber) und dem Österreichischen Bundesministerium für Unterricht, Kunst und Kultur.

Our grateful thanks for their generous support and help go to the following persons: Mrs Gertrude Vogel (Pulkau), $\mathrm{Mr}$ Helmut Peschina (Wien), Dr Norbert Griesmayer (Wien), Dr Elisabeth Lebensaft (Österreichisches biographisches Lexikon, Wien).

We gratefully acknowledge the financial support of the Austrian Society for Literature (Ms Marianne Gruber) and the Austrian Ministry for Education, Arts and Culture.

(c) by Gertrude Vogel (German text) and the Translators (English text) 2008

ISSN 0111-3283

ISBN 0-9582716-3-1

Printed in New Zealand 